\title{
Rating of resource-oriented countries based on aggregated sustainable development indexes
}

\author{
V. Khinkiladze, M.A. Nevskaya \\ Department of Economics, Organization and Management, St. Petersburg Mining University, St. \\ Petersburg, Russia
}

\begin{abstract}
Today, there is an acute problem of ensuring the universal wellbeing of humanity, based on the principles of sustainability. This problem is especially urgent for countries with a resource-oriented economy. This study considers the possibility of using adequate methods and indicators for assessing sustainable development, as well as building a ranking based on the data obtained, in countries with different levels of economic development and various human, natural, financial and material resources that determine the possibilities and lines of development for a dedicated group of resource-oriented economies. As a result of this study, it was revealed that today there is no single method capable of assessing the level of sustainable development of a particular country, the very indicators of certain raw material countries are difficult to compare sue to their subjectivity and, in their turn, require unification for more accurate analysis.
\end{abstract}

\section{Introduction}

For more than 20 years, leading international organizations and individual research teams have been working on the development of methodological approaches to the quantitative assessment of sustainability [1]. By 2020, a large number of methodologies were presented, the most significant of which: the indicator system proposed by the UN Commission on Sustainable Development, the OECD indicator system, the World Bank indicator system, and others. Analysis showed that the main and objective direction of the solution remains the system of indicators that allow us to give a quantitative assessment [2].

The purpose of this study is to analyze existing methods and indicators for assessing sustainable development to build a rating of countries with a resource-oriented economy.

Research Objectives:

- Choice of resource-oriented countries.

- Selection of the most common, significant and generally accessible methods and indicators for assessing sustainable development (SD).

- Ranking a group of countries based on selected indices.

- Analysis of the data.

Resource-oriented countries include countries where the mining sector provides $10 \%$ of GDP and $40 \%$ of export [2]

The choice as the objects of study of countries with a resource-oriented economy is related to the assumption that their economic, social and environmental developmentlargely 
depends on the availability, condition and effective use of mineral resources [3]. At the same time, despite the presence of a rich resource base, countries cannot always develop dynamically and may be subject to a "mineral curse" [4].

Therefore, it is necessary to identify indicators based on which one can judge the economic growth of countries and the level of their development [5].

Resource-oriented economies on the Eurasian continent were selected as objects: Azerbaijan, Mongolia, Kazakhstan, the Republic of Kyrgyzstan, Laos, Norway, Uzbekistan, Turkmenistan, and the Russian Federation. The choice of these countries is justified by the dependence of the economies on significant and, at the same time, to varying degrees, on the use of mineral recourses, which have a direct impact on the national welfare and development of each of the above-mentioned countries.

Of all the selected countries, only Norway is a country with a high level of economic development;all the rest can be classified asdeveloping countries and groups with a level of development below average (Mongolia, Kyrgyzstan, Laos, Uzbekistan, Turkmenistan) or above average ( Russia, Kazakhstan, Azerbaijan) [6].

\section{Analysis of sustainable development indicators}

Official data from international agencies were used as sources of information for the analysis: the World Bank, the United Nations, the Organization for Economic Cooperation and Development (OECD), the Global Environmental Indicators Tracking Network (Yale), the International Economic Forum, and the World Wildlife Fund.

When selecting methods and indicators, the following was taken into account:

- The ability to obtain information from accessible sources - published reports

- Frequency of publication

- The use of aggregate indicators that allow ranking countries according to this indicator

- Selection of indicators characterizing the economic, social, and environmental aspects of SD.

The following indicators were selected as indicators that meet these requirements: the index of environmental sustainability, the global gender gap index, the index of peacefulness, social prosperity of LEGATUM, social progress, transformation, the ecological footprint, as well as the index of happiness, the Ginny index, and the human development index.

In total, these indices show a holistic picture of the country's development in three aspects of SD. Table 1 provides general information about the selected indicators for assessing SD.

Table 1. Basic information on the applied indicators of SD

\begin{tabular}{|c|c|c|c|}
\hline $\begin{array}{c}\text { Indicator } \\
\text { Calculation model } \\
\text { Scope Source }\end{array}$ & $\begin{array}{l}\text { Indicator Calculation model } \\
\text { Scope Source }\end{array}$ & $\begin{array}{c}\text { Indicator } \\
\text { Calculation } \\
\text { model Scope } \\
\text { Source }\end{array}$ & $\begin{array}{l}\text { Indicator } \\
\text { Calculation } \\
\text { model Scope } \\
\text { Source }\end{array}$ \\
\hline $\begin{array}{l}\text { Environmental } \\
\text { Performance } \\
\text { Index }\end{array}$ & $\begin{array}{l}\text { Used to assess the country's } \\
\text { achievements in terms of } \\
\text { environmental status and natural } \\
\text { resource management based on } 22 \\
\text { qualitative and quantitative } \\
\text { indicators. }\end{array}$ & $\begin{array}{l}\text { Covers } 180 \\
\text { countries, } \\
\text { published } \\
\text { annually }\end{array}$ & $\begin{array}{l}\text { United } \\
\text { Nations } \\
\text { Development } \\
\text { Program } \\
\text { (UNDP) Yale } \\
\text { university }\end{array}$ \\
\hline
\end{tabular}




\begin{tabular}{|c|c|c|c|}
\hline $\begin{array}{c}\text { Ecological } \\
\text { Footprint Index }\end{array}$ & $\begin{array}{l}\text { Used to measure pressure } \\
\text { (impact) on the environment of } \\
\text { any person, enterprise, } \\
\text { organization, locality, country, } \\
\text { and population of the whole } \\
\text { planet. Measured in GGA - global } \\
\text { hectares. This conventional unit is } \\
\text { understood to mean } 1 \text { ha of } \\
\text { biologically productive land or } \\
\text { water with an average world level } \\
\text { of biological productivity for a } \\
\text { given year. }[7,8]\end{array}$ & $\begin{array}{l}\text { Covers } 180 \\
\text { countries, } \\
\text { published } \\
\text { annually }\end{array}$ & $\begin{array}{l}\text { WWF, Global } \\
\text { Footprint } \\
\text { Network }\end{array}$ \\
\hline $\begin{array}{l}\text { Global Gender } \\
\text { Development } \\
\text { Index }\end{array}$ & $\begin{array}{l}\text { Used to assess the level of the } \\
\text { gender gap that exists in one or } \\
\text { another country between women } \\
\text { and men } \\
{[9]}\end{array}$ & $\begin{array}{l}\text { Covers } 149 \\
\text { countries, } \\
\text { published } \\
\text { annually }\end{array}$ & UNDP \\
\hline $\begin{array}{l}\text { Global Peace } \\
\text { Index }\end{array}$ & $\begin{array}{l}\text { Used to assess the level of } \\
\text { violence within the state and the } \\
\text { level of aggressiveness of its } \\
\text { foreign policy. Compiled based } \\
\text { on } 23 \text { qualitative and quantitative } \\
\text { indicators combined into } 3 \text { main } \\
\text { groups: the presence and scale of } \\
\text { conflicts, the level of stability and } \\
\text { security within the state, the level } \\
\text { of militarization of the state. } \\
{[10]}\end{array}$ & $\begin{array}{l}\text { Covers } 163 \\
\text { countries, } \\
\text { published once } \\
\text { every two years }\end{array}$ & $\begin{array}{l}\text { IEF } \\
\text { Commission }\end{array}$ \\
\hline $\begin{array}{l}\text { Social Progress } \\
\text { Index }\end{array}$ & $\begin{array}{l}\text { Used to measure the achievement } \\
\text { of the countries of the world in } \\
\text { terms of social well-being and } \\
\text { social progress. Over } 50 \\
\text { indicators are taken into account, } \\
\text { combined into three main groups: } \\
\text { basic human needs, the basis of } \\
\text { human well-being, and the } \\
\text { possibility of human } \\
\text { development. }[11,12]\end{array}$ & $\begin{array}{l}\text { Covers } 149 \\
\text { countries, } \\
\text { published } \\
\text { annually }\end{array}$ & $\begin{array}{l}\text { The Social } \\
\text { Progress } \\
\text { Imperative }\end{array}$ \\
\hline Happiness index & $\begin{array}{l}\text { Used to measure the } \\
\text { achievements of countries of the } \\
\text { world and individual regions in } \\
\text { terms of their ability to provide } \\
\text { their residents with a happy life. } \\
\text { [13] }\end{array}$ & $\begin{array}{l}\text { Covers } 140 \\
\text { countries, } \\
\text { publishes every } \\
\text { two orthree } \\
\text { years }\end{array}$ & $\begin{array}{l}\text { New } \\
\text { Economic } \\
\text { Foundation }\end{array}$ \\
\hline
\end{tabular}




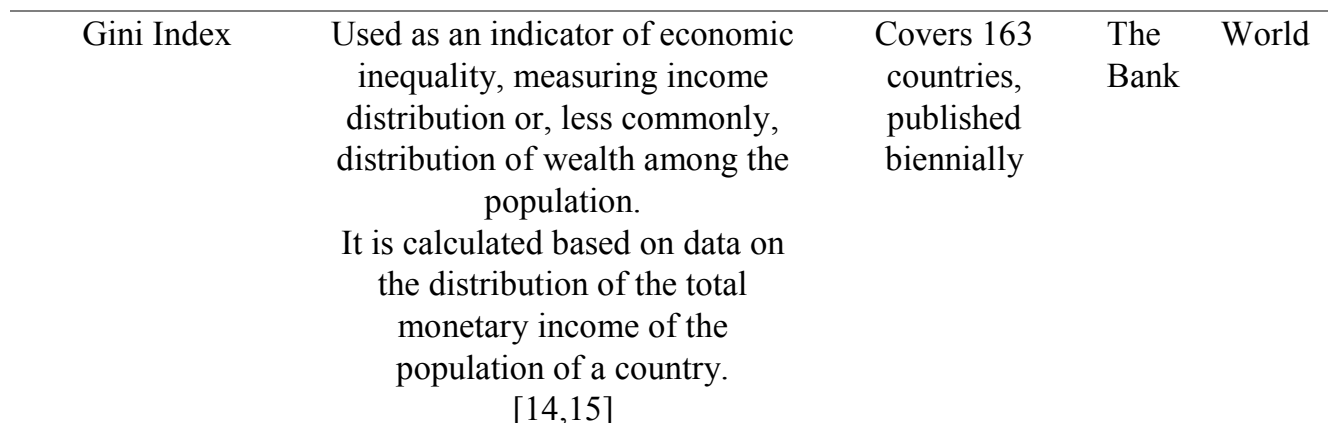

\begin{tabular}{|c|c|c|c|}
\hline $\begin{array}{l}\text { Transformation } \\
\text { Index }\end{array}$ & $\begin{array}{l}\text { Used for a comparative analysis } \\
\text { of the level of development of } \\
\text { democracy and a market } \\
\text { economies in developing and } \\
\text { transition countries, as well as the } \\
\text { quality of political governance in } \\
\text { these countries based on } \\
\text { standardized issues. } \\
{[16]}\end{array}$ & $\begin{array}{l}\text { Covers } 128 \\
\text { countries, } \\
\text { published } \\
\text { biennially }\end{array}$ & OECD \\
\hline $\begin{array}{c}\text { Human } \\
\text { Development } \\
\text { Index (HDI) }\end{array}$ & $\begin{array}{c}\text { Used to assess a country's } \\
\text { achievement in terms of health } \\
\text { status, education, and the actual } \\
\text { income of its citizens (United } \\
\text { Nations Development Program } \\
{[17]}\end{array}$ & $\begin{array}{l}\text { Covers } 189 \\
\text { countries, } \\
\text { published } \\
\text { annually }\end{array}$ & UNDP \\
\hline $\begin{array}{c}\text { LEGATUM } \\
\text { Prosperity Index }\end{array}$ & $\begin{array}{l}\text { Used to assess the achievements } \\
\text { of the countries of the world in } \\
\text { terms of their well-being and } \\
\text { prosperity. Issued by the British } \\
\text { analytical center The Legatum } \\
\text { Institute. } \\
{[18]}\end{array}$ & $\begin{array}{l}\text { Covers } 189 \\
\text { countries, } \\
\text { published } \\
\text { annually }\end{array}$ & $\begin{array}{c}\text { UNDP and } \\
\text { the World } \\
\text { Bank }\end{array}$ \\
\hline
\end{tabular}

\subsection{Inference}

Thus, the subsequent analysis of SD indicators should indicate the problems of their application [19], but it should also be noted that during the analysis itself the following problems arose inthe use of indicators:

- Lack of universal methods for their calculation

- Insufficiency and inaccessibility of information

- Industry specifics of countries were not taken into account when constructing them.

Note that the calculation methods presented in Table 1 are largely similar, as evidenced by the criteria for their calculation and the expert (point-based) method of bringing them to an aggregated form [20]. 
The least coverage is observed in the transformation index, which is explained by the specifics of thesample of developing countries for its calculation.

We also note that of all the presented indices, only the HDI takes into account the income index estimated through GNI at purchasing power parity and can be represented by the formula, which undoubtedly facilitates the subsequent calculations related to this index. $[21,22]$

Table 2 presents a grouping of the selected indicators and their values in three areas of SD: economic, social, and environmental for 2018.

The choice of 2018 is due to the availability of information for each of the indicators, taking into account the frequency of their calculation [23].

Table 2. Data of selected countries on indicators of sustainable development for 2018

\begin{tabular}{|c|c|c|c|c|c|c|c|c|c|c|}
\hline \multirow[t]{2}{*}{ Index } & \multicolumn{4}{|c|}{ Social indicators } & \multicolumn{4}{|c|}{ Economic indicators } & \multicolumn{2}{|c|}{$\begin{array}{l}\text { Environmental } \\
\text { performance }\end{array}$} \\
\hline & $\begin{array}{l}\text { Happ } \\
\text { ylife } \\
\text { index }\end{array}$ & $\begin{array}{c}\text { Glo } \\
\text { bal } \\
\text { Gen } \\
\text { der } \\
\text { Gap } \\
\text { Ind } \\
\text { ex }\end{array}$ & $\begin{array}{c}\text { Glo } \\
\text { bal } \\
\text { Pea } \\
\text { ce } \\
\text { Ind } \\
\text { ex }\end{array}$ & $\begin{array}{c}\text { Soci } \\
\text { al } \\
\text { Prog } \\
\text { ress } \\
\text { Inde } \\
x\end{array}$ & $\begin{array}{c}\text { LEGA } \\
\text { TUM } \\
\text { Prospe } \\
\text { rity } \\
\text { Index }\end{array}$ & $\begin{array}{c}\text { Transfor } \\
\text { mation } \\
\text { Index }\end{array}$ & $\begin{array}{l}\mathrm{H} \\
\mathrm{DI}\end{array}$ & $\begin{array}{c}\mathrm{Gi} \\
\mathrm{nn} \\
\mathrm{y} \\
\text { Ind } \\
\mathrm{ex}\end{array}$ & $\begin{array}{c}\text { Ecolo } \\
\text { gical } \\
\text { footpr } \\
\text { int } \\
\text { (GG } \\
\text { A / } \\
\text { perso } \\
\text { n) }\end{array}$ & $\begin{array}{c}\text { Environ } \\
\text { mental } \\
\text { Perform } \\
\text { ance } \\
\text { Index }\end{array}$ \\
\hline $\begin{array}{c}\text { Azerbai } \\
\text { jan }\end{array}$ & - & $\begin{array}{l}0.6 \\
87\end{array}$ & $\begin{array}{l}2.4 \\
54\end{array}$ & - & - & 4.13 & $\begin{array}{l}0.7 \\
54\end{array}$ & - & - & 62.33 \\
\hline $\begin{array}{c}\text { Kazakh } \\
\text { stan }\end{array}$ & 19.1 & $\begin{array}{c}0.7 \\
1\end{array}$ & $\begin{array}{l}1.9 \\
74\end{array}$ & $\begin{array}{c}67.2 \\
6\end{array}$ & 59.19 & 4.7 & $\begin{array}{l}0.8 \\
17\end{array}$ & $\begin{array}{c}27 . \\
4\end{array}$ & 5.6 & 54.56 \\
\hline $\begin{array}{c}\text { Kyrgyz } \\
\text { stan }\end{array}$ & 33.1 & $\begin{array}{l}0.6 \\
89\end{array}$ & - & $\begin{array}{c}65.7 \\
9 \\
\end{array}$ & 55.15 & 5.9 & $\begin{array}{l}0.6 \\
74\end{array}$ & $\begin{array}{c}27 . \\
4\end{array}$ & 1.9 & - \\
\hline Laos & - & $\begin{array}{l}0.7 \\
34\end{array}$ & $\begin{array}{l}1.8 \\
21\end{array}$ & $\begin{array}{c}47.5 \\
8\end{array}$ & 48.74 & - & $\begin{array}{l}0.6 \\
04\end{array}$ & - & - & 42.94 \\
\hline $\begin{array}{l}\text { Mongol } \\
\text { ia }\end{array}$ & 14.3 & $\begin{array}{l}0.7 \\
06\end{array}$ & $\begin{array}{l}1.8 \\
21\end{array}$ & $\begin{array}{c}65.1 \\
7\end{array}$ & 55.14 & - & $\begin{array}{l}0.7 \\
35\end{array}$ & $\begin{array}{c}33 . \\
8\end{array}$ & 6.1 & 57.51 \\
\hline Russia & 18.7 & $\begin{array}{l}0.7 \\
06 \\
\end{array}$ & $\begin{array}{c}3.1 \\
6\end{array}$ & $\begin{array}{c}70.1 \\
6\end{array}$ & 57.89 & 5.31 & $\begin{array}{l}0.8 \\
24\end{array}$ & $\begin{array}{c}41 . \\
6\end{array}$ & 5.7 & 63.69 \\
\hline $\begin{array}{l}\text { Turkme } \\
\text { nistan }\end{array}$ & 14.6 & - & $\begin{array}{l}2.2 \\
83\end{array}$ & - & - & 3.14 & $\begin{array}{l}0.7 \\
10 \\
\end{array}$ & - & 5.5 & 66.1 \\
\hline $\begin{array}{c}\text { Uzbeki } \\
\text { stan }\end{array}$ & 29.1 & - & $\begin{array}{l}2.1 \\
44\end{array}$ & $\begin{array}{c}59.5 \\
5\end{array}$ & - & 3.73 & $\begin{array}{l}0.7 \\
54\end{array}$ & - & 2.3 & 45.88 \\
\hline Norway & 36.8 & $\begin{array}{l}0.8 \\
42\end{array}$ & $\begin{array}{l}1.5 \\
19\end{array}$ & $\begin{array}{c}90.2 \\
6\end{array}$ & 84.53 & - & $\begin{array}{l}0.9 \\
53\end{array}$ & $\begin{array}{c}25 . \\
9\end{array}$ & 5 & 77.49 \\
\hline
\end{tabular}

* Dashes for individual indicators are associated either with the calculation methodology (2-year period) or with the lack of data for a specific period

In order to rank the countries according to the analyzed indicators, divided by three main areas of SD in Tables 3, 4 and 5, it is necessary to take into account the peculiarities of calculating each of the indicators. It is important to point out that the indicators of minimization are the Ginny Index and the Global Peace Index, and the maximization indicators are all other indicators. The comparison should be made only between indicators comparable in their purpose. 


\section{Ranking of countries by indicators of ur}

Table 3. Environmental SD indicators

\begin{tabular}{ccccc}
\hline Index & $\begin{array}{c}\text { Environmental } \\
\text { Performance } \\
\text { Index }\end{array}$ & $\begin{array}{c}\text { Ecological } \\
\text { footprint } \\
\text { (GGA } / \\
\text { person) }\end{array}$ & $\begin{array}{c}\text { Total } \\
\text { Cumulative } \\
\text { rating }\end{array}$ \\
Azerbaijan & 4 & - & - & - \\
Kazakhstan & 6 & 5 & 11 & 4 \\
Kyrgyzstan & - & 1 & - & - \\
Laos & 8 & - & - & - \\
Mongolia & 5 & 7 & 12 & 5 \\
Russia & 3 & 6 & 9 & 2 \\
Turkmenistan & 2 & 4 & 6 & 3 \\
Uzbekistan & 7 & 2 & 9 & 1 \\
Norway & 1 & 3 & 4 & 2 \\
\hline
\end{tabular}

Table 4. Social indicators of SD

\begin{tabular}{|c|c|c|c|c|c|c|}
\hline Index & $\begin{array}{l}\text { Global } \\
\text { Gender } \\
\text { Gap } \\
\text { Index }\end{array}$ & $\begin{array}{l}\text { Global } \\
\text { Peace } \\
\text { Index }\end{array}$ & $\begin{array}{l}\text { Social } \\
\text { Progress } \\
\text { Index }\end{array}$ & $\begin{array}{l}\text { Happin } \\
\text { ess index }\end{array}$ & $\begin{array}{r}\mathrm{T} \\
\text { otal }\end{array}$ & $\begin{array}{l}\text { Cumulat } \\
\text { ive rating }\end{array}$ \\
\hline $\begin{array}{l}\text { Azerbaijan } \\
\text { Kazakhstan }\end{array}$ & $\begin{array}{l}6 \\
3\end{array}$ & $\begin{array}{l}6 \\
3\end{array}$ & $\overline{2}$ & $\overline{4}$ & $2^{-}$ & $\overline{2}$ \\
\hline $\begin{array}{l}\text { Kyrgyzstan } \\
\text { Laos }\end{array}$ & $\begin{array}{l}5 \\
2\end{array}$ & $\overline{2}$ & $\begin{array}{l}3 \\
6\end{array}$ & $\begin{array}{l}2 \\
-\end{array}$ & - & $\begin{array}{l}- \\
-\end{array}$ \\
\hline Mongolia & 9 & 2 & 4 & 7 & $2^{2}$ & 5 \\
\hline Russia & 7 & 7 & 2 & 5 & $1^{2}$ & 4 \\
\hline $\begin{array}{l}\text { Turkmenist } \\
\text { an }\end{array}$ & 2 & 5 & - & 6 & - & - \\
\hline Uzbekistan & 7 & 4 & 5 & 3 & 9 & 3 \\
\hline Norway & 2 & 1 & 1 & 1 & 5 & 1 \\
\hline
\end{tabular}

\subsection{Inference}

At first glance, it may seem that the index of happiness is rather arbitrary and subjective, and the presented results may surprise in the considered group of countries. This can be explained by the fact that to compare the standard of living in different countries, they use either the GDP indicator or the HDI, which do not fully reflect the real state of things, in contrast to the happiness index, which considers the person's main goal on the part of satisfaction with their life [24]. 
Table 5. Economic indicators of SD

\begin{tabular}{|c|c|c|c|c|c|c|}
\hline Index & $\begin{array}{l}\text { LEGAT } \\
\text { UM } \\
\text { Prosperity } \\
\text { Index }\end{array}$ & $\begin{array}{l}\text { Transformat } \\
\text { ion Index }\end{array}$ & $\begin{array}{l}\text { HD } \\
\text { I }\end{array}$ & $\begin{array}{l}\text { Ginny } \\
\text { Index }\end{array}$ & $\begin{array}{l}\text { Tot } \\
\text { al }\end{array}$ & $\begin{array}{l}\text { Cumulative } \\
\text { rating }\end{array}$ \\
\hline Azerbaijan & - & 4 & 4 & - & - & - \\
\hline $\begin{array}{l}\text { Kazakhsta } \\
\text { n }\end{array}$ & 2 & 3 & 3 & 2 & 10 & 2 \\
\hline $\begin{array}{c}\text { Kyrgyzsta } \\
n\end{array}$ & 4 & 1 & 8 & 2 & 15 & 5 \\
\hline Laos & 6 & - & - & - & - & - \\
\hline Mongolia & 5 & - & 6 & 3 & 14 & 4 \\
\hline Russia & 3 & 2 & 2 & 4 & 11 & 3 \\
\hline $\begin{array}{l}\text { Turkmenis } \\
\tan \end{array}$ & - & 6 & 7 & - & - & - \\
\hline Uzbekistan & - & 5 & 5 & - & - & - \\
\hline Norway & 1 & - & 1 & 1 & 3 & 1 \\
\hline
\end{tabular}

Note that many of the above indicators do not relate exclusively to one direction of SD their designation is conditional but conditioned by methods and criteria for their calculation, which, in their turn, largely illuminate a certain lineof SD [25].

From the above information, it is clear that due to lack of data, several countries did not get into the ranking;therefore, only four countries ranked in all three areas of SD are included in the final ranking.

The data is presented in Table 6 .

Table 6. Final ranking

\begin{tabular}{lc}
\hline Index & Final ranking \\
Kazakhstan & 2 \\
Kyrgyzstan & 5 \\
Mongolia & 4 \\
\hline Russia & 3 \\
\hline Norway & 1
\end{tabular}

\subsection{Inference}

Considering the final ranking, it was found that there is a correlation with the differences in countries in terms of economic development, which is confirmed by data from the Little Green Book (Little Green Book - an online database of SD indicators) [25].

\section{Conclusion}

In the conclusion of this work, it is necessary to present the following results and recommendations made during the study:

1. Despite a large number of indicators of various kinds, both environmental, economic, and social, there was currently no single method for assessing a country's level of 
sustainable development. The problem led to an objective error in the assessment of a country's level of sustainable development, as well as its directions.

2. Data from commodity countries are difficult to compare, either because of the availability of data or because of the subjectivity of expert estimates. The latter was currently rather acute, as expert estimates were not always well-founded, and lack of data could be an indication of the fact that countries are not fully aware of the importance of ensuring the well-being of all through SD indicators.

3. There is an urgent need to harmonize and unify indicators to carry out the most accurate and comprehensive analysis and to develop a strategy for their improvement and development. There is also a need to establish a common method for all countries capable of assessing the level of sustainable development and, if expert opinions were provided.

The reported study was funded by rfbr and mcessm according to the research project№ 19-510$44013 \backslash 19$.

\section{Referencec}

1. V.V. Butvilovsky, About the realities of "sustainable development", Altai: Proceedings of the Al-Thai Branch of the Russian Geographical Society, 2 (53), 5-6 (2019).

2. P.M. Kaznacheyev, Natural rent and economic growth, (St. Petersburg: Russian Academy of National Economy and Public Administration under the President of the Russian Federation 2013).

3. V.V. Yurak, A.V. Dushin, L.A. Mochalova, Protiv ustojchivogo razvitiya: scenario budushchego, Zapiski Gornogo Instituta, 242, 242-247 (2020).

4. N. Weitz, H. Carlsen, M. Nilsson, K. Skonberg, Towards a systematic and contextual setting of priorities for implementing the 2030 agenda, Science of Sustainability, 13 (2), 531-548 (2017).

5. D.D. Moyer, B. Brooke, Alternative Ways to Develop Human Potential: Assessing Trade-offs and Synergies in Achieving Sustainable Development Goals. Futures 105, 199-210 (2019).

6. T. Ponomarenko, M. Nevskaya, O. Marinina, An Assessment of the Applicability of Sustainability Measurement Tools to Resource-Based Economies of the Commonwealth of Independent States, Sustainability, 12, 5582 (2020).

7. Global Footprint Network, 2018. [Official site] Available at: http://www.footprintnetwork.org/en/index.php/GFN/(date of request: 13.02.2020)

8. A. Tsvetkova, E. Katysheva, Ecological and economic efficiency evaluation of sustainable use of mineral raw materials in modern conditions Ecological and economic efficiency evaluation of sustainable use of mineral raw materials in modern conditions. International Multidisciplinary Scientific GeoConference Surveying Geology and Mining Ecology Management. SGEM 2017, 17(53), 259-266 (2017).

9. World Economic Forum, 2018. [Official site] Available at: http://reports.weforum.org(date of request: 17.05.2020)

10. The Imperative of Social Progress, 2018. [Official site] Available at: https://www.socialprogress.org/(date of request: 13.02.2020)

11. Michael E. Porter, S. Stern, M. Green, Social Progress Index, (Washington: The imperative of social progress 2017). 
12. New Economic Fund, 2018. [Official site] Available at: http://happyplanetindex.org/)(date of request: 15.02.2020)

13. World Data Atlas, 2018. [Official site] Available at https://knoema.ru/atlas/)(date of request: 25.04 .2020 )

14. A. Cherepovitsyn, A. Ilinova, Ecological, economic and social issues of implementing carbon dioxide sequestration technologies in the oil and gas industry in Russia, Journal of Ecological Engineering, 17(2), 19-23 (2016).

15. United Nations Development Program (UNDP), 2018. [Official site] Available at: http://hdr.undp.org/ (date or request: 10.03.2020)

16. Bertelsman Foundation, 2018. [Official site] Available at: http://www.btiproject.org/index (date of request: 25.04 .2020 )

17. LEGATUM Institute, 2018. [Official site] Available at: https://www.prosperity.com/(date of request: 13.02.2020)

18. Y. Lu, N. Nakichenovich, M. Visbek, A.C. Stevans, Politics: Five Priorities for the UN Sustainable Development Goals - Comment. Nature 520 (7548), 432-433 (2015).

19. V.S. Litvinenko, The social and market mechanism of sustainable development of public companies in the mineral resource sector, Eurasian Mining, (2020). DOI: $10.17580 / \mathrm{em} .2020 .01 .07$

20. O.A. Nesterova, O.V. Pozharnitskaya, Assessment of wealth from a position of sustainable human development: the possibilities of international indices, Issues of innovative economics, 3, 336-346 (2018).

21. E. Carayannis, A. Cherepovitsyn, A. Ilinova, Sustainable Development of the Russian Arctic zone energy shelf: the Role of the Quintuple Innovation Helix Model, Journal of the Knowledge Economy, 8(2), 456-470 (2017).

22. O. Marinina, Analysis of trends and performance of CSR mining companies, IOP Conference Series: Earth and Environmental Science, 302(1), 1-7 (2019).

23. K. Christian, A. Warhold, P. Pradhan, Sustainable Development Goals (SDGs): have we managed to turn trade-offs into synergies?, (Germany: Palgrave Commun 2019).

24. D. Vaaj, C. Yap, S. Bell, C. Levy, D. Mays, T. Pegram, S. Mayhew, Managing the UN Sustainable Development Goals: Collaboration, Infrastructure, and Institutions, The Lancet Global Health, 3, 251 - 252 (2015).

25. Little Green Book. The level of economic development. [Official site] Available at: https://www.littlegreenbook.co.uk/(date of request: 21.04.2020) (2020) 